Pak. j. sci. ind. res. Ser. A: phys. sci. 2017 60(1) 34-41

\title{
Appraisal of Drinking Water Quality in Lahore Residence, Pakistan
}

\author{
Khalid Mahmood ${ }^{\text {a* }}$ and Muhammad Asim ${ }^{\mathrm{b}}$ \\ ${ }^{a}$ Remote Sensing and GIS Group, Department of Space Science, University of the Punjab, Lahore, Pakistan \\ ${ }^{b}$ Department of Space Science, University of the Punjab, Lahore, Pakistan \\ (received February 14, 2016; revised June 8, 2016; accepted August 11, 2016)
}

\begin{abstract}
A comprehensive study for the spatial distribution of drinking water quality had been conducted for residential area of Lahore, Pakistan. The study had made use of the geographic information system (GIS) for geographical representation and spatial analysis of groundwater quality. Physicochemical parameters including electric conductivity, $\mathrm{pH}$, TDS, $\mathrm{Cl}, \mathrm{Mg}$, Ca, alkalinity and bicarbonates from 73 of the water samples had been included in the analysis. Water quality data had been geo-referenced followed by its interpolation using inverse distance weighted (IDW) for each of the parameters. Very high alkalinity and bicarbonates values were observed in most parts of the area. For the comprehensive view, water quality index map had been prepared using weighted overlay analysis (WOA). The water quality index map was classified into five zones of excellent, good, poor, very poor and unfit for drinking as per WHO standards of drinking water. $21 \%$ region had excellent quality of the underground water and $50 \%$ was found good for drinking. Poor quality of water was found in southeastern part, covering $27 \%$ of the study area. Only $2 \%$ of the area was found under the very poor and unfit water quality conditions for drinking.
\end{abstract}

Keywords: drinking water quality, groundwater, water quality index, GIS, weighted overlay

\section{Introduction}

Groundwater is one of the most important resources available to humanity for their social and economic growth (Nwanwoala et al., 2012; Christophoridis et al., 2011). It is the most suitable form of fresh water as it contains almost balanced salt concentration, which is good for human use. Despite the fact that earth has a lot of water, only $2.5 \%$ of the earth's total water is fresh and only one-third of this small amount of fresh water is available for human use (PCRWR, 2007; Hassan et al., 2005). Recent developments in living standard, agriculture and industrialisation have greatly increased the demand of the groundwater (Mahmood et al., 2013). In arid and semi-arid regions the total water withdrawn for human usage has almost tripled from $1382 \mathrm{~km}^{3} /$ year in 1950 to $3973 \mathrm{~km}^{3} /$ year in 2000 and the worldwide projection has predicted that human water consumption would reach to $5235 \mathrm{~km}^{3} /$ year by 2025 (Clarke and King, 2004).

Any addition of undesirable substances to groundwater by human or natural activities is called contamination. Once a local aquifer is contaminated, it is almost impossible to clean it up as the cost of its purification is usually very high. Owing to its unique characteristics such as hydrogen bonding and polarity, water has ability

*Author for correspondence; E-mail: khalid.m270@yahoo.com to dissolve many components which leads to its contamination. The quality of groundwater is equally important as its quantity (Mahmood et al., 2013; Majandang and Sarapirome, 2013; Rehman, 2008), therefore, environmental protection policies give highest priority to its monitoring (Mahmood et al., 2013). Monitoring of water resources for its quality is necessary to avoid any outbreak of water born diseases (Ullah et al., 2013). Groundwater always moves by the force of gravity from recharge areas to the areas of its discharging. Its movement in most areas is slow as few feet per year, but in more permeable areas such as channels in limestone, movement could be as much as several feet per day.

Listed parameters by researchers that can alter groundwater contamination are $\mathrm{pH}$, electric conductivity (EC), turbidity, salinity, total dissolved solids (TDS), alkalinity, bicarbonates, chloride, calcium, oil, grease and heavy metals (Brindha et al., 2014; Singh et al., 2014; Verma et al., 2013; Usali and Ismail, 2010). Groundwater is monitored in many parts of the world, mainly by measuring groundwater levels, groundwater recharge, and its contamination level. The results of these measurements are often interpolated and combined with other information to produce various groundwater thematic maps at local and regional scales. Over the time, many countries and states have developed groundwater mapping programmes for their entire territory or 
for areas in which their most important groundwater resources are located. World-wide Hydro-geological Mapping and Assessment Programme (WHYMAP) thus bring together the huge efforts in hydro-geological mapping at regional, national and continental levels.

It is widely reported that degradation of groundwater is arising due to overexploitation of groundwater in Pakistan, India and other developing countries (Moench and Dixit, 2004). Currently fresh water stress in Pakistan has reached over $40 \%$ and the situation is going to get worse by the year 2025, just like other countries of the world. Lashari et al. (2007) estimated that about 60$70 \%$ population of Pakistan depends directly or indirectly on groundwater for its livelihood.

The mega city Lahore, Pakistan is facing serious challenges for the provision of safe and sufficient drinking water and the situation is predicted to be getting more severe in coming days.

The present study therefore, was conducted for spatial analysis of groundwater quality in this area.

\section{Materials and Methods}

Study area. The mega city of Lahore with an area of 17,000 hectares is provincial capital of Punjab and second largest city of Pakistan. It lies between Bari Doab and Rechna Doab, and is located along bank of river Ravi. It is located between $31^{\circ} 15^{\prime}-31^{\circ} 45^{\prime} \mathrm{N}$ and $74^{\circ} 01^{\prime}$ and $74^{\circ} 39^{\prime} \mathrm{E}$ with an average height of $217 \mathrm{~m}$ above the mean sea level (Fig. 1). It is delimited on the north with the Sheikhupura district, in the east with Wagah boarder and in the south with Kasur district. The river Ravi flows on the northern and western out skirts of the city (Mahmood et al., 2013).

The climate of the study area is hot and semi-arid with long and intensely hot summers, dry and warm winters, monsoon and mud storms. The average rainfall is about $575 \mathrm{~mm} /$ year but it can vary in the range of $300-1200 \mathrm{~mm}$ providing $40 \%$ recharge to the groundwater.

The area is underlain by $300 \mathrm{~m}$ thick bed of alluvial deposits, as investigated by WASID during the period of 1961-62 (WAPDA, 1980). The major recharge source for local aquifer is river Ravi, that flows now occasionally and BRBD Canal on the aquifer behaves as a single contiguous, unconfined aquifer. Underlying strata wise the area consisted predominantly of sand, silt and thin lenses of clay.

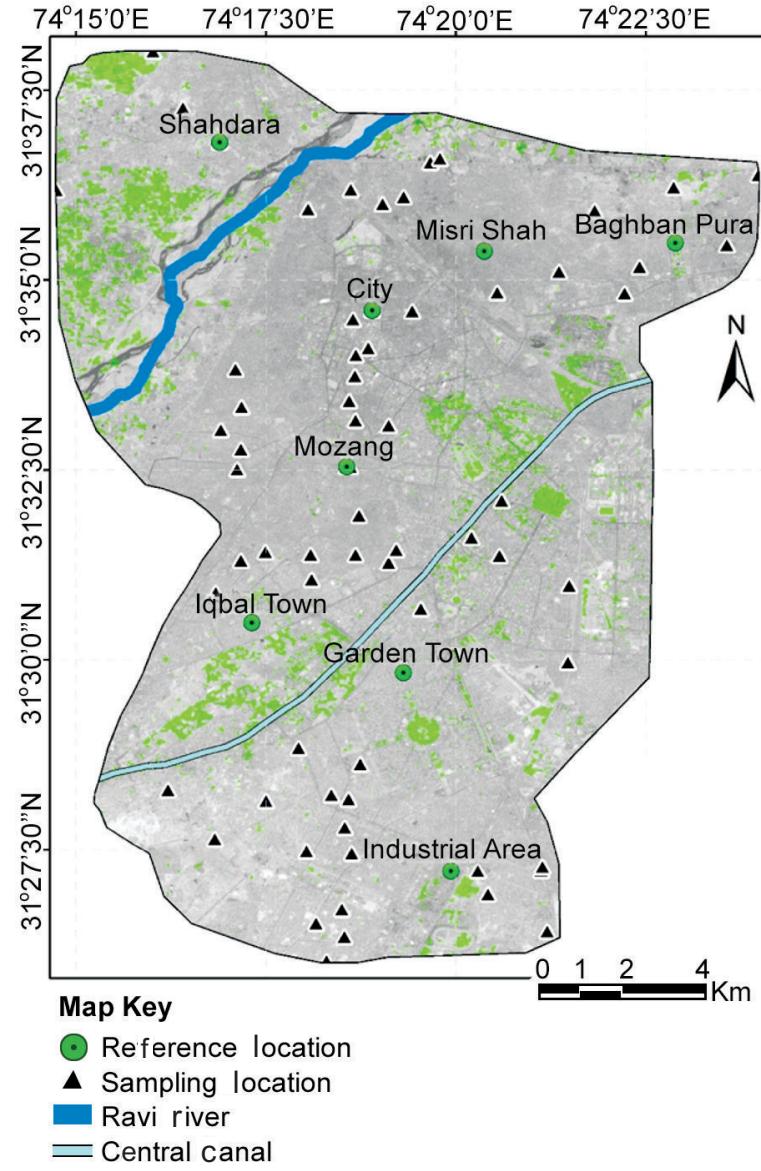

Fig. 1. Study area.

Provision of water supply to most of the study area is responsibility of Water and Sanitation Agency (WASA), Lahore. Water quality data for the year 2012 was acquired from WASA, Lahore, which periodically collects water samples from their installed tube wells in residential area of Lahore. They analysed collected water samples in their laboratory for 19 of the drinking water quality parameters. The analyses of the water samples carried out through standard methods for examination of water (APHA-AWWA-WPCF) as per WHO guildlines for drinking water (WHO, 2011). The analysed parameters include temperature, odor, colour, taste, $\mathrm{pH}$, turbidity, TDS, conductivity, total hardness, $\mathrm{Ca}, \mathrm{Mg}$, alkalinity, $\mathrm{Cl}, \mathrm{NO}_{2}, \mathrm{NO}_{3}, \mathrm{CO}_{3}, \mathrm{HCO}_{3}$ and E. coli (Table 1).

A total of 73 well seperated groundwater samples from residential area of the city had been chosen to carry out this work. Parameters considered for this study include $\mathrm{pH}$, total dissolved solids (TDS), chloride (Cl), electrical conductivity (EC), bicarbonates $\left(\mathrm{HCO}_{3}\right)$, alkalinity (alk), 
Table 1. Water quality data used in the study

\begin{tabular}{|c|c|c|c|c|c|c|c|c|c|c|}
\hline No. & Location & Subdivision & $\mathrm{pH}$ & Alkalnity & TDS & $\mathrm{EC}$ & $\mathrm{Ca}$ & $\mathrm{Mg}$ & $\mathrm{Cl}$ & $\mathrm{HCO}_{3}$ \\
\hline 1 & 2-D-1 Green Town & Green Town & 8.1 & 204 & 350.2 & 556 & 11.2 & 7.68 & 16 & 204 \\
\hline 2 & 3-C-1 Township & Green Town & 7.8 & 324 & 396.9 & 630 & 25.6 & 15.4 & 27 & 324 \\
\hline 3 & 3-D-1 Green Town. & Green Town & 8.1 & 202 & 385.5 & 612 & 11.2 & 10 & 17 & 202 \\
\hline 4 & 5-D-1 Green Town & Green Town & 7.8 & 366 & 687.9 & 1,092 & 38.4 & 27.8 & 32 & 366 \\
\hline 5 & 5-D-2 Kir Kalan Village & Green Town & 7.8 & 344 & 652.6 & 1,036 & 28.8 & 24.5 & 30 & 344 \\
\hline 6 & A3 Johar Town & Johar Town & 7.8 & 424 & 720 & 1,143 & 32.8 & 29.7 & 24 & 424 \\
\hline 7 & A-Block Gulshan Ravi & Krishan Nagar & 8.1 & 210 & 372.9 & 592 & 36 & 24.9 & 28 & 210 \\
\hline 8 & Abu Bakar Block. & Garden Town & 8 & 370 & 517.8 & 822 & 38.4 & 27.3 & 35 & 370 \\
\hline 9 & Adda Crown Bus & Anarkali & 8 & 242 & 618.6 & 982 & 33.6 & 30.7 & 46 & 242 \\
\hline 10 & Aibak Park Mozang & Mozang & 7.8 & 296 & 849.8 & 1,349 & 72.8 & 48 & 10 & 296 \\
\hline 11 & Akbari Gate (New) & City & 7.8 & 414 & 652.6 & 1,036 & 14.4 & 24.5 & 103 & 414 \\
\hline 12 & Alia Town & Baghban Pura & 7.8 & 200 & 280.3 & 445 & 49.6 & 24.5 & 31 & 200 \\
\hline 13 & Aslam Iqbal Park & Mozang & 8.1 & 246 & 392.4 & 623 & 32.8 & 18.7 & 45 & 246 \\
\hline 14 & Awa Pahari Queens Rd Mozang & Mozang & 8.1 & 148 & 495.1 & 786 & 60 & 21.1 & 103 & 148 \\
\hline 15 & Awami Colony & Industrial Area & 8 & 244 & 447.9 & 711 & 19.2 & 13.9 & 25 & 244 \\
\hline 16 & Aziz Colony Chatha Park & Farrukhabad & 7.9 & 360 & 553.7 & 879 & 64.8 & 36.5 & 84 & 360 \\
\hline 17 & Bank Stop Main Fazal e Haq Co & Industrial Area & 7.9 & 370 & 669 & 1,062 & 24 & 21.6 & 55 & 370 \\
\hline 18 & B-Block, Gulberg II & Gulberg & 7.8 & 180 & 395 & 627 & 19.2 & 13.4 & 23 & 180 \\
\hline 19 & Cattle Park & Anarkali & 7.8 & 252 & 293.7 & 625 & 60 & 36.5 & 49 & 252 \\
\hline 20 & C-Block, Faisal Town & Garden Town & 8.1 & 302 & 380.5 & 612 & 25 & 18 & 15 & 302 \\
\hline 21 & Chah Motia Data Nagar & Data Nagar & 7.8 & 216 & 249.4 & 396 & 49.6 & 19.7 & 39 & 216 \\
\hline 22 & China scheme & Misri Shah & 7.9 & 188 & 248.8 & 395 & 24.8 & 16.3 & 15 & 188 \\
\hline 23 & Clifton Colony & Iqbal Town & 8.1 & 190 & 299.8 & 476 & 19.2 & 10 & 20 & 190 \\
\hline 24 & D-Block, Faisal Town. & Garden Town & 8 & 220 & 301 & 478 & 16.8 & 10.6 & 20 & 220 \\
\hline 25 & Dhobi Mandi & Anarkali & 7.8 & 304 & 406.3 & 646 & 57.6 & 32.2 & 65 & 304 \\
\hline 26 & Dhoop Sari & Krishan Nagar & 8 & 164 & 175.1 & 278 & 28.8 & 17.8 & 11 & 164 \\
\hline 27 & E-Block Johar Town & Johar Town & 7.9 & 334 & 746.1 & 1,213 & 32.8 & 24.5 & 20 & 334 \\
\hline 28 & F-1 Block Johar Town & Johar Town & 8.3 & 324 & 463 & 735 & 43.2 & 27.4 & 24 & 324 \\
\hline 29 & Faisal Park & Farrukhabad & 7.8 & 200 & 202.2 & 321 & 35.2 & 19.7 & 28 & 200 \\
\hline 30 & Fareed Colony & Industrial Area & 7.9 & 400 & 714.4 & 1,134 & 40.8 & 29.3 & 48 & 400 \\
\hline 31 & Fareed Kot & Anarkali & 7.8 & 350 & 933.6 & 1,482 & 80 & 48 & 68 & 350 \\
\hline 32 & Farrukhabad & Farrukhabad & 8.1 & 184 & 332.6 & 528 & 39.2 & 17.2 & 23 & 184 \\
\hline 33 & FC Block Gulberg II & Gulberg & 8 & 160 & 282.2 & 448 & 16.8 & 15.8 & 19 & 160 \\
\hline 34 & Foot Ball Ground Gulshan Ravi & Krishan Nagar & 8 & 170 & 176.4 & 280 & 32.8 & 15.4 & 17 & 170 \\
\hline 35 & G IV Block Johar Town & Johar Town & 8.3 & 158 & 299.2 & 475 & 12.8 & 10 & 14 & 158 \\
\hline 36 & General Hospital & Industrial Area & 8.2 & 282 & 479.4 & 761 & 21.6 & 11.5 & 24 & 282 \\
\hline 37 & Hanif Park Tonda Phatak & Data Nagar & 8 & 122 & 190.8 & 303 & 20 & 10.8 & 15 & 122 \\
\hline 38 & Huma Block & Iqbal Town & 7.8 & 180 & 261.4 & 415 & 24.6 & 13.4 & 34 & 180 \\
\hline 39 & Hussain Park & Data Nagar & 8.2 & 164 & 223 & 354 & 40.8 & 18.9 & 15 & 164 \\
\hline 40 & Jahanzaib Block & Iqbal Town & 7.8 & 160 & 245.7 & 390 & 25.6 & 11.5 & 13 & 160 \\
\hline 41 & Jinnah Park Sultan Pura & Misri Shah & 8.2 & 186 & 395.6 & 628 & 48.8 & 20.6 & 67 & 186 \\
\hline 42 & Kamran Park & Farrukhabad & 8.1 & 160 & 240 & 381 & 66 & 12 & 23 & 160 \\
\hline 43 & Kanchi Stop & Industrial Area & 7.8 & 446 & 834.1 & 1,324 & 40 & 24.5 & 40 & 446 \\
\hline 44 & Kanji House Gujjar Pura & Misri Shah & 7.8 & 162 & 332 & 527 & 26.4 & 15.8 & 14 & 162 \\
\hline 45 & Karmabad, Rehman Pura & Ichra & 8 & 242 & 249.4 & 396 & 21.6 & 7.2 & 18 & 242 \\
\hline 46 & Khokhar Road \# 3 & Data Nagar & 8.1 & 126 & 163.1 & 259 & 32.8 & 11.5 & 10 & 126 \\
\hline 47 & Lahori Gate & City & 7.8 & 222 & 400.6 & 636 & 58.4 & 24.5 & 45 & 222 \\
\hline 48 & Madhulal Hussain & Baghban Pura & 8.3 & 184 & 364.1 & 578 & 24.8 & 11.5 & 22 & 184 \\
\hline 49 & Makkah Colony (New) & Gulberg & 7.8 & 284 & 492.6 & 782 & 27.2 & 19.7 & 30 & 284 \\
\hline 50 & Match Factory & Farrukhabad & 8.1 & 246 & 369.8 & 587 & 51.2 & 19.6 & 13 & 246 \\
\hline 51 & Mehmood Booti Disposal & Baghban Pura & 8.1 & 180 & 199 & 316 & 25.6 & 15.8 & 10 & 180 \\
\hline 52 & Mori Gate & City & 7.9 & 186 & 243.8 & 387 & 192 & 19.7 & 18 & 186 \\
\hline 53 & Napier Road & Anarkali & 7.8 & 346 & 824 & 1,308 & 60 & 21.1 & 130 & 346 \\
\hline 54 & Nargis Block & Iqbal Town & 7.9 & 270 & 553.1 & 878 & 46.4 & 26.9 & 48 & 270 \\
\hline 55 & N-Block, Model Town Ext. & Garden Town & 7.8 & 400 & 589 & 935 & 43.2 & 26.4 & 32 & 400 \\
\hline 56 & Neelum Block & Iqbal Town & 7.8 & 234 & 518.4 & 823 & 35.2 & 20.6 & 59 & 234 \\
\hline 57 & Nisar Press Gulberg & Gulberg & 7.8 & 462 & 817.1 & 1,297 & 45.6 & 34.1 & 55 & 462 \\
\hline 58 & Rasool Park & Ichra & 8.3 & 126 & 422.7 & 671 & 47.2 & 22.1 & 105 & 126 \\
\hline 59 & Rehman Pura & Ichra & 8 & 226 & 545.5 & 866 & 16.8 & 9.6 & 23 & 226 \\
\hline 60 & Rustam Park & Krishan Nagar & 7.8 & 230 & 454.8 & 722 & 32 & 20.6 & 51 & 230 \\
\hline 61 & Saad di Mill & Baghban Pura & 8.1 & 240 & 287.2 & 456 & 34.4 & 15.4 & 15 & 240 \\
\hline 62 & Saadi Park & Mozang & 8.2 & 294 & 355.9 & 565 & 35.2 & 16.3 & 56 & 294 \\
\hline 63 & Sawami Nagar (Old) & Misri Shah & 8.1 & 206 & 510.9 & 811 & 41.6 & 32.6 & 98 & 206 \\
\hline 64 & Shah di Khoi & Johar Town & 7.8 & 382 & 481.9 & 765 & 48 & 12.9 & 22 & 382 \\
\hline 65 & Shah Kamal (New) & Ichra & 8 & 184 & 521 & 827 & 17.6 & 11.4 & 18 & 184 \\
\hline 66 & Siddique Pura & Data Nagar & 8 & 134 & 204.7 & 325 & 24.8 & 12.5 & 10 & 134 \\
\hline 67 & Surria Jabeen Park & Baghban Pura & 7.8 & 202 & 477.5 & 758 & 44 & 23.5 & 34 & 202 \\
\hline 68 & Takia Lehri Shah & Ichra & 7.8 & 234 & 600.3 & 953 & 40.8 & 20.6 & 58 & 234 \\
\hline 69 & Takia Mehmood Shah & Krishan Nagar & 8.1 & 242 & 166.9 & 265 & 27.2 & 17.3 & 15 & 242 \\
\hline 70 & Timber Market & City & 7.9 & 220 & 228.6 & 363 & 15.2 & 10.1 & 28 & 220 \\
\hline 71 & Usman Block & Garden Town & 7.9 & 254 & 430.9 & 684 & 34.4 & 17.8 & 62 & 254 \\
\hline 72 & Wasan Pura & Misri Shah & 8 & 168 & 252.6 & 401 & 28.8 & 18.7 & 20 & 168 \\
\hline 73 & Zafar Ali Rd Gulberg V & Gulberg & 8 & 194 & 367.9 & 584 & 16 & 10.1 & 23 & 194 \\
\hline
\end{tabular}


Magnesium (Mg) and Calcium (Ca). All this collected data is shown in Table 1 and their corresponding statistics are given in Table 2 .

An overview of the used methodology is given in Fig. 2. The spatial reference to each of the sampled location had been measured using global position system (GPS). The used model of GPS for ground survey was GPSmap-76CSx receiver, having horizontal accuracy of $\pm 3 \mathrm{~m}$. All the quality data were then georeferenced using the location data in the form of a point shapefile

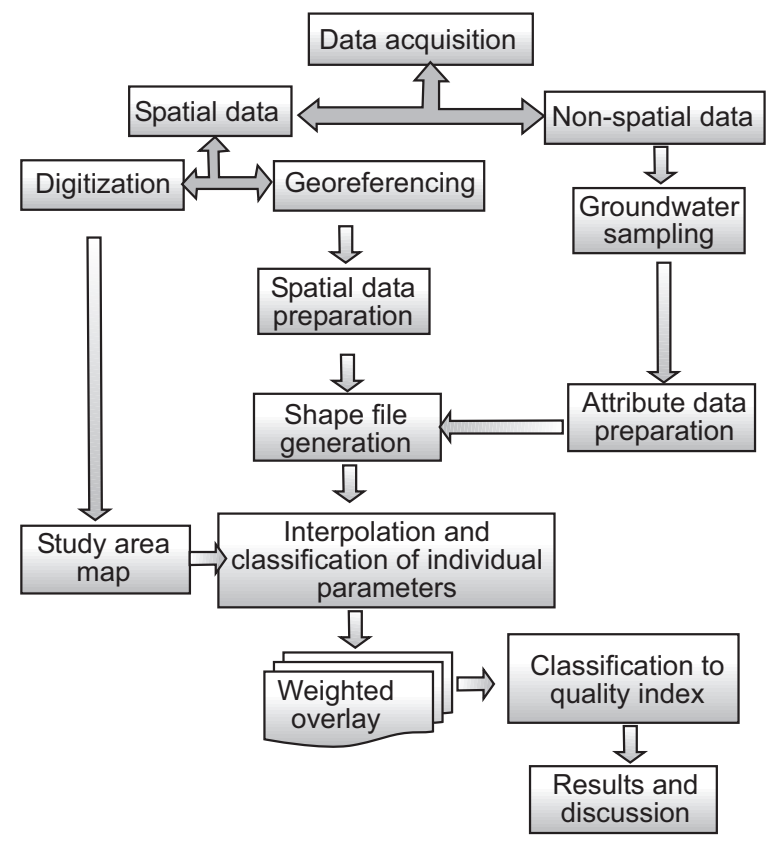

Fig. 2. Flow chart of methodology. in ArcGIS 9.3. The point data was then interpolated to generate continuous rasters for each of the selected water quality parameters. The used technique of interpolation, Inverse Distance Weighted (IDW) belongs to deterministic family of interpolators as suggested by a number of previous studies (Bairu et al., 2012; Latha et al., 2012; Abulhakeem et al., 2011; Balakrishnan et al., 2011; Singh et al., 2011; Latha et al., 2010).

IDW is based on the fact that the nearby values are more related to each other than values that are far apart. In other words, for this spatial interpolation technique the influence of a known data point is inversely related to the distance from the unknown location, being estimated (Shepard, 1968). The mathematical expression of the inverse distance weighted is given as:

$$
\mathrm{z}_{\mathrm{o}}=\frac{\sum_{\mathrm{i}=1}^{\mathrm{s}} \mathrm{z}_{\mathrm{i}} \frac{1}{\mathrm{~d}_{\mathrm{i}}^{\mathrm{k}}}}{\sum_{\mathrm{i}=1}^{\mathrm{s}} \mathrm{z}_{\mathrm{i}} \frac{1}{\mathrm{~d}_{\mathrm{i}}^{\mathrm{k}}}}
$$

where:

$\mathrm{z}_{\mathrm{O}}=$ estimated value at point-o; $\mathrm{z}_{\mathrm{i}}=$ the value at known point- $\mathrm{i} ; \mathrm{d}_{\mathrm{i}}=$ is the distance between point- $\mathrm{i}$ and point$\mathrm{o} ; \mathrm{s}=$ the number of known points used in estimation and $\mathrm{k}=$ the specified power.

Boundry of the Lahore residents is marked/digitized using Quick Bird imegery having spatial resolution of $2.6 \mathrm{~m}$, improved to $0.6 \mathrm{~m}$ by high resolution merging. Layers obtained from the interpolation contains continuous values for each of the parameters which make

Table 2. Data statistics and applicable classification scheme

\begin{tabular}{|c|c|c|c|c|c|c|}
\hline Parameter & Min & Max & Mean & Range & Assigned value & Weight \\
\hline Eletric conductivity $(\mathrm{EC})(\mu \mathrm{S} / \mathrm{cm})$ & 260 & 1469 & 864.5 & $\begin{array}{l}<500 \\
500-1000 \\
>1000\end{array}$ & $\begin{array}{l}1 \\
2 \\
3\end{array}$ & 12 \\
\hline $\mathrm{pH}$ & 7.80 & 8.29 & 8.05 & $\begin{array}{l}7.5-8.0 \\
>8.0\end{array}$ & $\begin{array}{l}2 \\
3\end{array}$ & 16 \\
\hline TDS (mg/L) & 169 & 929 & 549 & $\begin{array}{l}<500 \\
500-1000\end{array}$ & $\begin{array}{l}1 \\
2\end{array}$ & 28 \\
\hline $\mathrm{HCO}_{3}(\mathrm{mg} / \mathrm{L})$ & 122 & 481 & 301.5 & $\begin{array}{l}<240 \\
240-400 \\
>400\end{array}$ & $\begin{array}{l}1 \\
2 \\
3\end{array}$ & 9 \\
\hline $\mathrm{Cl}(\mathrm{mg} / \mathrm{L})$ & 10 & 129 & 69.89 & $<250$ & 1 & 8 \\
\hline $\mathrm{Ca}(\mathrm{mg} / \mathrm{L})$ & 11 & 191 & 101 & $<75$ & 1 & 8 \\
\hline $\mathrm{Mg}(\mathrm{mg} / \mathrm{L})$ & 7.2 & 47.7 & 27.45 & $\begin{array}{l}<30 \\
30-75\end{array}$ & $\begin{array}{l}1 \\
2\end{array}$ & 8 \\
\hline Alkalanity (mg/L) & 1221 & 481 & 301.5 & $\begin{array}{l}<200 \\
240-400 \\
>400\end{array}$ & $\begin{array}{l}1 \\
2 \\
3\end{array}$ & 12 \\
\hline
\end{tabular}


data more complex. To overcome this problem of diversity in parameteric values all the rasters have been classsified as per WHO standard classification. This three-classes scheme of WHO for each of the parameters has been used by a number of researchers for groundwater quality assessment (Bairu et al., 2013; Latha et al., 2012; Abulhakeem et al., 2011; Balakrishnan et al., 2011; Singh et al., 2011; Latha et al., 2010).

Finally the water quality index (WQI) is calculated through weighted overlay analysis (WOA). WOA is a GIS based framework to conceptulize a spatial phenomenon depending over more than one geographic parameters as is the case of groundwater quality. Weights have been assigned to each of the constituting quality parameter showing their relative importance in overall quality indexing. These weights have been assigned to the parameters following earlier studies by Bauru et al. (2013) and Latha et al. (2012). The assigned weights are shown in Table 2.

Maximum weight of 28 had been assigned to TDS showing its dominating significance in water quality assessment. $\mathrm{Cl}, \mathrm{Ca}$ and $\mathrm{Mg}$ are assigned the minimum weight of 8 , as they have relatively low importance in the overall quality assessment of groundwater (Bairu et al., 2013; Latha et al., 2012). Other parameters like, electric conductivity, bicarbonates and $\mathrm{pH}$ are given weights between 8 and 28 depending on their relative significance for the phenomenon. Ratings and weights are multiplied to calculate final output. Finally the water quality index is computed through WOA and had been classified as excellent, good, poor, very poor and unfit for drinking purpose depending on their degree of fitness for human consumption.

\section{Results and Discussion}

The study has prepared thematic maps for each of the studied quality parameters and then their common representation has been made using WQI map for the year 2012. Variation of the EC was within the permissible limit of $1,500 \mu \mathrm{S} / \mathrm{cm}$ at $25^{\circ} \mathrm{C}$ as suggested by WHO. However, lower values were mostly concentrated in northern parts of the study area comprising of Farrukhabad (Shahdra), Data Nager, Baghban Pura, Krishan Nager and few patches of westerly located Iqbal Town, and Johar Town as well. Higher values were found in Gulberg, Industrial area, Mozang, Anarkali and a portion of Johar Town sub-divisions. Spatial distributions of electric conductivity (EC) of the underground aquifer is shown in Fig. 3A.
All of the study has been found well within the range of maximum acceptable limit of $\mathrm{pH}$ for drinking water i.e., 9.2 as per WHO standards. In this way groundwater of the area is mainly neutral to slightly alkaline in nature. As per WHO classification scheme only two classes were formed in the measure range of the $\mathrm{pH}$ value. Second ranked category covers the maximum area while Class 3 has some portions of Furrakhabad, Krishan Nager, Mozang, Johar Town, Green Town and Industrial area sub-divisions. Spatial distributions of $\mathrm{pH}$ concentrations are shown in Fig. 3B. Spatial concentration of $\mathrm{Cl}$ is given in Fig. 3C, where all the sample data lies in a single class. The permissible limit for $\mathrm{HCO}_{3}$ is $240 \mathrm{mg} / \mathrm{L}$ and only $21 \%$ of the study area is found under this permissible limit. Spatial distribution of $\mathrm{HCO}_{3}$ is shown in Fig. 3D. Maximum of the study area is found with $500 \mathrm{mg} / \mathrm{L}$ of TDS, whereas higher values are found in parts of Anarkali and Mozang sub-divisions as shown in Fig. 3E. Dissolve magnesium in water is the most common mineral that makes water hard, $98 \%$ of the groundwater samples were found within the desirable limits $(30 \mathrm{mg} / \mathrm{L})$, whereas higher values had been found in Mozang, Misri shah, Gulberg, Anarkali and Furrakabad

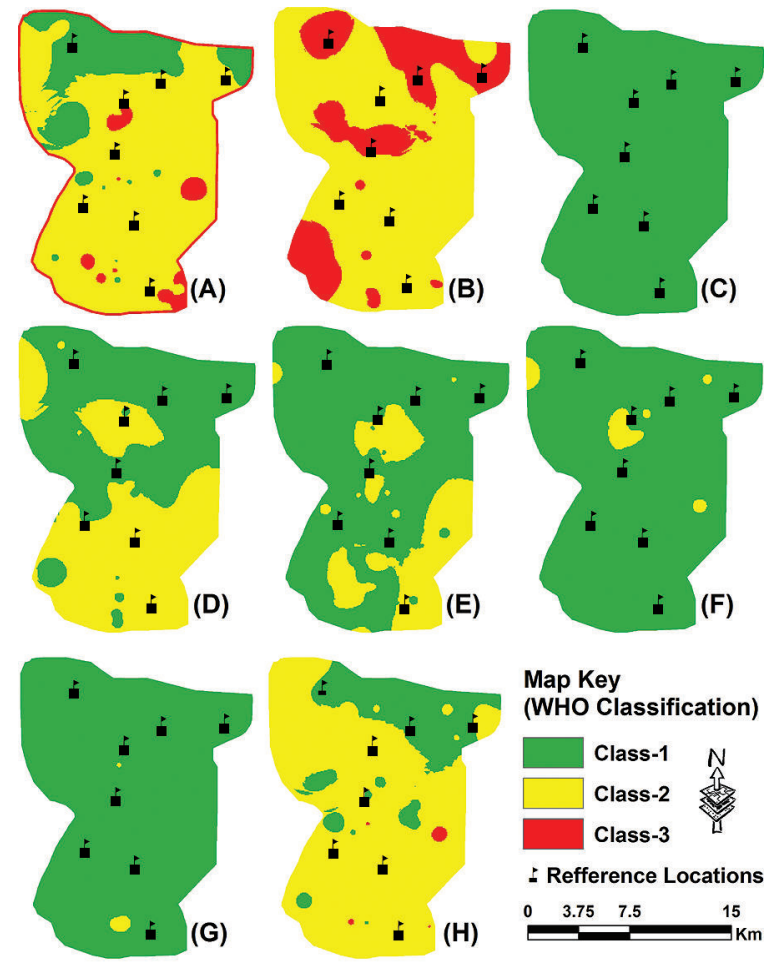

Fig. 3. Spatial distribution of individual parameters (A)-EC; (B)-pH; (C)-Cl: (D)- $\mathrm{HCO}_{3}$; (E)TDS; (F)-Mg; (G)-Ca: (H)-alkalanity. 
sub-divisions as shown in Fig. 3F. There are two spots of higher $\mathrm{Ca}$ concentration, one found between Anarkali and Mozang and the other at southern side of the study area, as shown in Fig. 3G.

About $21 \%$ of the study area was under permissible limits of alkalinity and the areas under relatively extreme conditions were distributed over patches of Johar Town and Gulberg sub-divisions as shown in Fig. 3H. High concentration of alkalinity in these areas may be the result of huge construction work including under passes and a flyover, involved heavy drilling in ground. All the measured and predicted values of $\mathrm{Cl}$ are almost similar and fall in one of the three classes defined by WHO. Similarly $\mathrm{Ca}$ is within the permissible limits and formed two of WHO classes. It is notable that the common regions for extreme measures of majority of the parameters are Mozang and Anarkali subdivisions.

Water quality index. The water quality index values have been divided into classes of excellent, good, poor, very poor and unfit for drinking. Layer generated in this way is further subjected for calculation of areas corresponding to each of the class which shows that $21 \%$ of the study area is under excellent conditions,

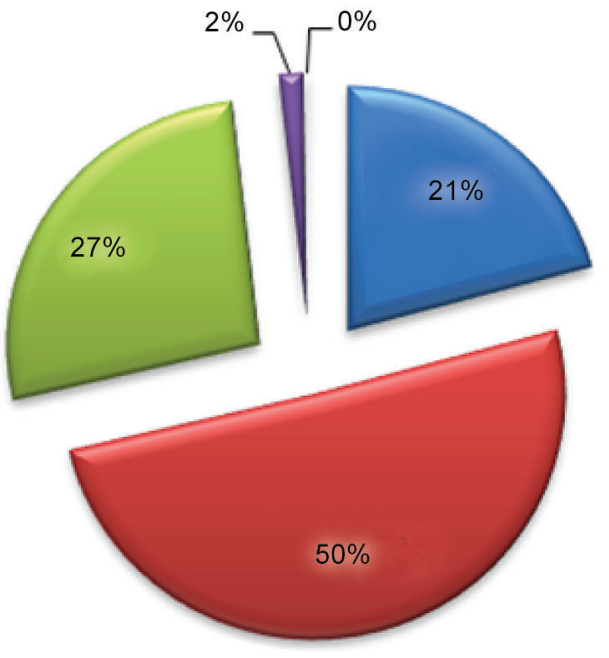

Excellent

- Good

Poor

Very poor

Unfit for drinking

Fig. 4. Drinking water suitability area comparison chart as per WHO standard classification.
$50 \%$ is good, $27 \%$ is poor, less than $2 \%$ is very poor and a very small portion of the region is found unfit for drinking. This area wise comparison of different classes is depicted in Fig. 4.

The hot spot that is classified as unfit for drinking is found at the same region which was stated to have the deepest groundwater levels in the Lahore (Mahmood et al., 2013). The same region is found prominent in most of the individual parameters maps (TDS, $\mathrm{HCO}_{3}$, $\mathrm{EC}$ and alkalinity) for their high values as shown in Fig. 2. Very poor quality of groundwater is centered at the depression centre of ground water in the city and its chunks have also been found at out skirts of the study area including parts of Gulberg, Johar Town and Anarkali subdivisions. Poor quality groundwater is found mostly in south eastern parts of the study area however, its patches are also found in Anarkali, Misri Shah and Furrakabad subdivisions. $71 \%$ of the study

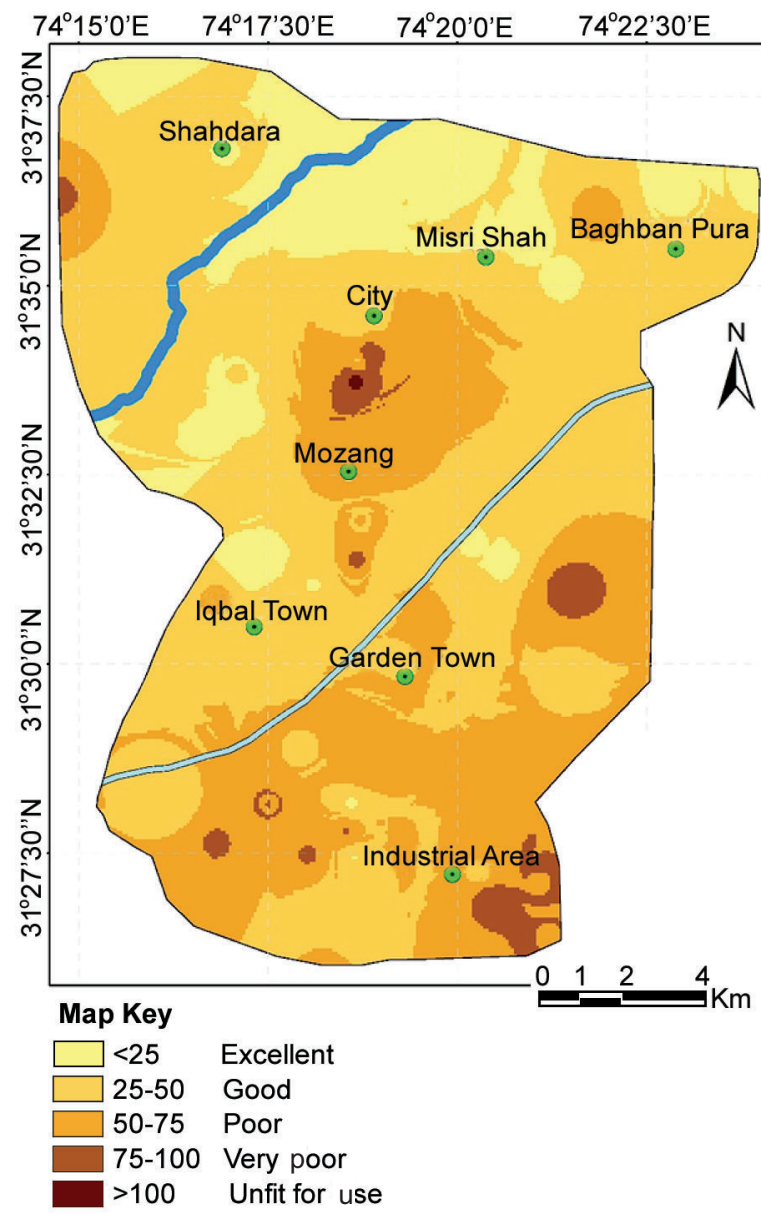

Fig. 5. Water quality index map. 
area is found under good and excellent groundwater conditions that is located in the north, the only exception exist around the central depression zone.

The existence of concentering zones of gradually degrading water quality in the central portion of the study area as shown in Fig. 5 shows that the quality of extracted water is somehow linked to over exploitation of the fresh water resource. There is no recharge from this portion of the area and water reached there, by the lateral movement of the recharge from edges of the city. In this way degradation of the water quality seems to be occurring during its path through the underground materials.

\section{Conclusion}

This study concludes that groundwater quality parameters including $\mathrm{pH}$, electric conductivity, $\mathrm{Ca}, \mathrm{Cl}$ and TDS are well within the permissible limits defined by WHO for the drinking water. However alkalinity, $\mathrm{HCO}_{3}$ and $\mathrm{Mg}$ are crossing their respective safe limits in some parts of Lahore residence.

Groundwater in subdivisions of Gulberg, Anarkali and Mozang sub-divisions, is found to be marginally fit for drinking purpose. So these areas need special attention of authorities regarding provision of the safe drinking water to the community. Surrounding areas of the above mentioned locations have also been spotted to be touching upper limits of the safety margins, so in near future these regions of groundwater may also become unsuitable for human use. Estimation of the health damage done by intake of the polluted water can be made by the field observation, showing increased use of filtration plants in the Lahore residence.

Visible correlation between distribution of poor quality of groundwater and impervious surfaces along with high abstraction rates of water reflects that urbanisation is the root cause of all this environmental damage. High abstraction rates along with increasing pervious surfaces has already been reported to cause a cone like depression in under-ground aquifer cantered between Muzang and Anarkali subdivisions. This cone like depression causes the water to flow latterly from remote areas of recharge to discharge zones. This lateral flow may be the reason of dissolving substances from underlying lithology. The possible solution to the issue for the local government is to minimize this lateral flow, ultimately, reduce the depression. It is possible through locally distributed groundwater recharge facilities in the study area and controlling pumping rates. People awareness plans are necessary to stop unnecessary wastage of this precious fresh water resource for the sustainable development of the mega city of Lahore.

\section{References}

Abulhakeem, A., Ishaku, J.M., Ahmed, A.S. 2011. Mapping of water quality index using GIS in Kaltungo, Northeastern Nigeria. Journal of Environmental Sciences and Resource Management, 3: 94-106.

Bairu, A., Tadesse, N., Amare, S. 2013. Use of geographical information system and water quality index to assess suitability of groundwater quality for drinking purpose in Hewane Area, Tigray, Northern Ethiopa. Ethiopian Journal of Environmental Studies and Management, 6: 110-123.

Balakrishnan, P., Saleem, A., Mallikarjun, N.D. 2011. Groundwater quality mapping using geographic information system (GIS): A case study of Gulbarga City, Karnataka, India. African Journal of Environmental Science and Technology, 5: 1069-1084.

Brindha, K., Vaman, N.K.V., Srinivasan, K., Babu, S.M., Elango, L. 2014. Identification of surface watergroundwater interaction by hydrogeochemical indicators and assessing its suitability for drinking and irrigational purposes in Chennai, Southern India. Applied Water Science, 4: 159-174.

Christophoridis, C., Bizani, E., Fytianos, K. 2011. Environmental quality monitoring, using GIS as a tool of visualization, management and decisionmaking. Applications emerging from the EU water framework directive EU 2000/60. (http://www.irmainternational.org/viewtitle/70522/). pp. 1554-15560.

Clarke, R., King, J. 2004. The Water Atlas, 98 pp. The New Press, New York, USA.

Hassan, R., Scholes, R., Ash, A. 2005. Ecosystems and Human Well-Being: Current State and Trends, vol. 1, 170 pp. Island Press, Washington, DC., USA.

Lashari, B., McKay, J., Villholth, K. 2007. Institutional and legal groundwater management framework: Lessons learnt from South Australia for Pakistan. International Journal of Environmental and Development, 4: 45-59.

Latha, H.T., Kumar, P.G.N., Lakshminarayana, P., Anil, A. 2012. Assessment of groundwater quality index for upper Pincha basin, Chittoor district, Andhra Pradesh, India using GIS. International Journal of Scientific \& Engineering Research, 3: 1-8. 
Latha, S.P., Rao, N.K. 2010. Assement and spatial distribution of quality of groundwater in zone -II and III , Greater Viskhapatnam, India using Water Quality Index (WQI) and (GIS). International Journal of Environmental Sciences, 1: 198-212.

Mahmood, K., Daud, A., Tariq, S., Kanwal, S., Ali, R., Haider, A., Tahseen, T. 2013. Groundwater levels susceptibility to degradation in Lahore metropolitan. Science International, 25: 123-126.

Majandang, J., Sarapirome, S. 2013. Groundwater vulnerability assessment and sensitivity analysis in NongRua, KhonKaen, Thailand using a GISbased SINTACS Model. Environment Earth Sciences, 68: 2025-2039.

Moench, M., Dixit, A. 2004. Adaptive capacity and livelihood resilience, Adaptive strategies for responding to floods and droughts in South Asia. ISET (Institute for Social and Environmental Transition), Boulder, Khatmandu, Nepal.

Nwankwoala, H.O., Eludoyin, O.S., Obafemi, A.A. 2012. Groundwater quality assessment and monitoring using geographical information system (GIS) in Port Harcourt, Nigeria. Ethiopian Journal of Environmental Studies and Management (EJESM), 5: 583-596.

PCRWR, 2007. Water Quality Monitoring, Fifth Monitoring Report (2005-6). ISBN 978-969-8469-184, Pakistan Council of Research in Water Resources (PCRWR), Pakistan.

Rahman, A. 2008. A GIS based DRASTIC model for assessing groundwater vulnerability in shallow aquifer in Aligarh, India. Applied Geography, 28: $32-53$.
Singh, P., Khan, I.A. 2011. Ground water quality assessment of Dhankawadi ward of Pune by using GIS. International Journal of Geomatics and Geosciences, 2: 688-703.

Singh, U.V., Abhishek, A., Singh, K.P., Dhakate R., Singh, N.P. 2014. Groundwater quality appraisal and its hydrochemical characterization in Ghaziabad (a region of Indo-gigantic plain), UP, India. Applied Water Science, 4: 145-157.

Ullah, Z., Khan, H., Waseem, A., Mahmood, Q., Farooq, U. 2013. Water quality assessment of the river Kabul at Peshawar, Pakistan: Industrial and urban wastewater impacts. Journal of Water Chemistry and Technology, 35: 170-176.

Usali, N., Ismail, M.H. 2010. Use of remote sensing and GIS in monitoring water quality. Journal of Sustainable Development, 3: 228-238.

Verma, A., Thakur, B., Katiyar, S., Singh, D., Rai, M. 2013. Evaluation of ground water quality in Lucknow, Uttar Pradesh using remote sensing and geographic information systems (GIS). International Journal of Water Resources and Environmental Engineering, 5: 67-76.

WAPDA, 1980. Development Credit Agreement. Third Water and Power Development Authority (WAPDA), Power Project, International Development Association and Pakistan, United NationsTreaty Series, 1256: I-20601.

WHO, 2011. Guidelines for Drinking Water Quality, $4^{\text {th }}$ edition. http://www.unicef.org/cholera_toolkit/ chapter_4_prevention/01_WHO_G/guidelines_f or_drinking_water_quality.pdf.Access date: 13-022014. 